NOTICE: This is the author's version of a work that was accepted for publication in Electrochemistry Communications. Changes resulting from the publishing process, such as peer review, editing, corrections, structural formatting, and other quality control mechanisms may not be reflected in this document. Changes may have been made to this work since it was submitted for publication. A definitive version was subsequently published in Electrochemistry Communications, 13, 7, 2011. DOI: 10.1016/j.elecom.2011.04.020 


\title{
Haemoglobin unfolding studies at the liquid-liquid interface
}

\author{
Grégoire Herzog, ${ }^{\mathrm{a} *}$ Marie-Therese Nolan, ${ }^{a}$ Damien W.M. Arrigan ${ }^{\mathrm{b}}$ \\ a Tyndall National Institute, Lee Maltings, University College, Cork, Ireland \\ b Nanochemistry Research Institute, Department of Chemistry, Curtin University, Perth, WA 6845, \\ Australia.d.arrigan@curtin.edu.au \\ * Corresponding author T: + 353214904406 ; F: + 35321490 4467; e-mail: \\ gregoire.herzog@tyndall.ie
}

\begin{abstract}
The electrochemical behaviour of haemoglobin denatured using different concentrations of urea was investigated at the liquid|liquid interface. The reverse peak current varied with the concentration of urea, allowing the building of the unfolding curve, which compares well with UV-Vis absorbance results. Thermodynamic parameters, such as the change in free energy of folding in water, $\Delta G_{W}$, and the index of the compactness of the protein, $m$, were extracted from the experimental data. The work here presents a simple electrochemical method for the study of protein unfolding by electrochemistry at the liquid | liquid interface.
\end{abstract}

Keywords: Cyclic voltammetry, ITIES, haemoglobin, urea, protein unfolding 


\section{Introduction}

The function of protein is defined by its tertiary structure. Disruption of this tri-dimensional structure is due to a variety of factors (temperature, $\mathrm{pH}$, denaturing agents, solvents), which cause the loss of the protein activity. Protein unfolding / folding mechanisms are traditionally investigated by spectroscopic techniques (fluorescence, UV-Vis, circular dichroism) [1]. However, electrochemical methods have been developed to investigate protein unfolding mechanisms using, protein filmmodified electrodes [2-6] and mercury electrodes [7-8]. Detection of protein unfolding at proteinfilm electrodes is generally based on the release of redox-active groups, such as the haem groups of haemoglobin $(\mathrm{Hb})$. In the folded form of $\mathrm{Hb}$, the haem is buried within the structure and is not accessible for electron transfer reactions with the electrode. During the unfolding of $\mathrm{Hb}$, the haem becomes more and more available and increasing peak currents are observed for increasing denaturant concentrations [2-3]. At mercury electrodes, an electrocatalytic hydrogen evolution was used to distinguish between native and de-natured protein [7].

The electrochemical behaviour of proteins [9-15] at the interface between two immiscible electrolyte solutions (ITIES) has been reported recently. Proteins adsorb at the interface and assist the transfer of anions from the organic phase electrolyte to the aqueous phase. The complex formed between the protein adsorbed at the ITIES and the anions of the organic phase leads to changes in the protein conformation [10, 16]. These interactions between lipophilic anions and proteins adsorbed at the interface were confirmed by biphasic electrospray ionization mass spectrometry [17], where adsorbed lysozyme molecules form complexes with tetrakis(4-chlorophenyl)borate ( $\mathrm{TPBCl}^{-}$) of stoichiometry 1:1, 1:2 and 1:3 (lysozyme:TPBCl'). Recent studies have demonstrated that the electrochemical response of proteins at the ITIES is greatly influenced by disruptions of their structure, whether achieved by the presence of a chemical denaturant [18] or by proteolysis [19]. In the presence of urea, the electrochemical behaviour of $\mathrm{Hb}$ was greatly altered leading to a lower peak current and charge [18].

We report here the investigation of $\mathrm{Hb}$ unfolding by increasing urea concentrations monitored by cyclic voltammetry (CV) at the ITIES. The results obtained are compared to those achieved using UVVis spectroscopy studies.

\section{Experimental section}

\subsection{Reagents}

All chemicals were purchased from Sigma-Aldrich Ireland Ltd and were used as received. The organic phase electrolyte solution was 1,2-diclhoroethane (1,2-DCE) containing $10 \mathrm{mM}$ bis(triphenylphosphoranylidene) ammonium tetrakis(4-chlorophenyl)borate (BTPPA ${ }^{+} \mathrm{TPBCl}^{-}$), which was prepared by metathesis of bis-(triphenylphosphoranylidene) ammonium chloride (BTPPA ${ }^{+} \mathrm{Cl}^{-}$) and of potassium tetrakis(4-chlorophenyl)borate $\left(\mathrm{K}^{+} \mathrm{TPBCl}^{-}\right)$[20]. Purified water $(18.2 \mathrm{M} \Omega \mathrm{cm})$ used for all the aqueous solutions was from an Elgastat system (Elga, UK).

\subsection{Instrumentation}

A PGSTAT30 potentiostat (Ecochemie B.V., The Netherlands) was used for all electrochemical experiments. A four-electrode glass electrochemical cell was used, where the interfacial potential 
was controlled between the organic reference and the aqueous reference electrodes (both $\mathrm{Ag} \mid \mathrm{AgCl}$ wires). The current was measured using two Pt mesh counter electrodes. The geometric interfacial area was $1.12 \mathrm{~cm}^{2}$ and the interface was flat in appearance. A positive current corresponds to the transfer of a cation from the aqueous phase to the organic phase, or of an anion from the organic to the aqueous phase. A negative current corresponds to the transfer of a cation from the organic to the aqueous phase or of an anion from the aqueous to the organic phase. The UV-Vis spectra were obtained with a S12 Biochrom UV-Vis spectrophotometer (purchased from Brennan \& Company, Dublin, Ireland). The solutions analysed contained $100 \mu \mathrm{M} \mathrm{Hb}$ in $x \mathrm{M}$ Urea $+0.15 \mathrm{M} \mathrm{HCl}+0.15 \mathrm{M} \mathrm{KCl}$ (where $x$ is the concentration of urea in the solution). Absorbance measurements were made in a quartz cuvette at $\lambda=400 \mathrm{~nm}$.

\subsection{Method}

CV was used for all electrochemical investigations. An electrochemical cell containing both immiscible electrolyte solutions was set up as follows: $\mathrm{Ag}|\mathrm{AgCl}|$ Aqueous electrolyte $\mid 110 \mathrm{mM}$ $\mathrm{BTPPA}^{+} \mathrm{TPBCl}^{-}$in 1,2-DCE | Saturated solution of BTPPA ${ }^{+} \mathrm{Cl}^{-}$in $10 \mathrm{mM} \mathrm{LiCl}|\mathrm{AgCl}| \mathrm{Ag}$. Solutions of known concentration of $\mathrm{Hb}$ were prepared daily in the appropriate aqueous electrolytes $(10 \mathrm{mM} \mathrm{HCl}$ or $0.15 \mathrm{MKCl}+0.15 \mathrm{M} \mathrm{HCl}+x \mathrm{M}$ urea). Aliquots of these solutions were added to the aqueous phase electrolyte solution. All CVs were carried out in triplicate.

\section{Results and discussion}

Figure 1 shows the CVs of $\mathrm{Hb}$ at the ITIES with aqueous phases of $10 \mathrm{mM} \mathrm{HCl}$ or $0.15 \mathrm{M} \mathrm{HCl}+0.15 \mathrm{M}$ $\mathrm{KCl}$, the latter being the background electrolyte used for protein denaturation in the presence of urea. Significant differences can be observed due to the change of the electrolyte. The $0.15 \mathrm{M} \mathrm{HCl}+$ $0.15 \mathrm{M} \mathrm{KCl}$ solution has a $\mathrm{pH}$ of 0.8 as opposed to the $\mathrm{pH} 2$ of the $10 \mathrm{mM} \mathrm{HCl}$. The ionic strength, $I_{c}$, of the $0.15 \mathrm{M} \mathrm{HCl}+0.15 \mathrm{M} \mathrm{KCl}$ electrolyte solution is higher $(0.3 \mathrm{M})$ than that of the $10 \mathrm{mM} \mathrm{HCl}$ electrolyte solution $(0.01 \mathrm{M})$. Both $\mathrm{pH}$ and $I_{c}$ have a strong influence on the protein conformation [13] so changes in the voltammograms were expected. Scanlon et al. investigated the impact of these two parameters separately on the CVs of lysozyme at the ITIES [13]. An increase of the aqueous phase $\mathrm{pH}$ leads to an increase of the peak currents, whereas the peak currents decreased when the ionic strength of the solution increased. In Figure 1, the peak of the forward scan is attributed to the adsorption of the protein on the interface and protein-facilitated transfer of background anions from the organic phase; at the higher ionic strength, the forward peak is not as well-defined as for lysozyme $[13,17]$. However, a greater peak current $(i=-51.8 \mu \mathrm{A})$ is recorded on the reverse scan with the $0.15 \mathrm{M} \mathrm{HCl}+0.15 \mathrm{M} \mathrm{KCl}$ electrolyte solution than with the $10 \mathrm{mM} \mathrm{HCl}$ electrolyte solution $(i=-20.5 \mu \mathrm{A})$. In subsequent experiments, the aqueous phase selected was $0.15 \mathrm{M} \mathrm{HCl}+0.15 \mathrm{M} \mathrm{KCl}$. The presence of $4 \mathrm{M}$ urea in the $0.15 \mathrm{M} \mathrm{HCl}+0.15 \mathrm{M} \mathrm{KCl}$ solution resulted in a further increase of the reverse peak current $(i=-116.8 \mu \mathrm{A})$ for $5 \mu \mathrm{M} \mathrm{Hb}$ (Figure 1$)$. At low $\mathrm{pH}, \mathrm{Hb}$ is partially unfolded, with parts of the tertiary structure unaffected [21-23]. Urea destabilises hydrophobic interactions to fully unfold the protein structure [24]. 
$\mathrm{CVs}$ of $\mathrm{Hb}$ in the presence of increasing concentrations of aqueous phase urea are shown in Figure 2. On the forward scan, the peak for the adsorption of the protein changed somewhat with the urea concentration. However the reverse peak due to $\mathrm{Hb}$ was better defined and showed a better sensitivity to the concentration of urea (inset, Figure 2). A decrease in reverse peak current occurred around $4.5-5 \mathrm{M}$ urea and then leveled-off for urea concentrations greater than ca. $6 \mathrm{M}$. Urea interacts with both the hydrophobic and hydrophilic parts of $\mathrm{Hb}$, leading to the alteration of the hydrophobic interactions and hydrogen bonds that keep the protein in its native form [25-26]. Protein unfolding modifies its tertiary structure, leading to a change in the number of amino acids available for interaction with the anion of the organic electrolyte solution.

UV vis spectrophotometry and electrochemical results for urea induced $\mathrm{Hb}$ unfolding are compared (Figure 3). The unfolding percentage was calculated using equation (1) [27]:

$$
\text { Unfolding } \%=\frac{f-f_{f}}{f_{u}-f_{f}} \times 100
$$

where $f$ represents the peak current / absorbance value at a given urea concentration, $f_{f}$ the value in the native state and $f_{u}$ the value in the unfolded state. There is a shift of approximately 2 $\mathrm{M}$ for the half-wave urea concentration between the spectrophotometric and the electrochemical values. A similar shift was observed for $\mathrm{Hb}$ unfolding investigated at bare glassy carbon electrodes [2]. The difference may be due to the monitoring of different processes by the two methods. UV-vis spectrophotometry monitors the release of the haem prosthetic group from the protein matrix, while CV at ITIES monitors the ability of organic phase anions to interact with the adsorbed protein. These are distinct processes, so some difference may be expected in the results. The results obtained were further analysed by determining the change in free energy of folding in water, $\Delta G_{W}$, and $m$ the index of the compactness of the protein [27]. $\Delta G_{W}$ and $m$ can be extracted from the expression (2) [27]:

$$
\Delta G=\Delta G_{w}-m[\text { Urea }]
$$

$\Delta G$ is extracted from the experimental data using equation (3):

$$
\Delta G=-R T \ln \left(\frac{f_{f}-f}{f-f_{u}}\right)
$$

The thermodynamic parameters, shown in Table 1, compare well to the published data for the unfolding of $\mathrm{Hb}$ with urea using fluorescence and electrochemical measurements at a clay-modified electrode [6].

\section{Conclusions}


The unfolding of $\mathrm{Hb}$ by urea was monitored by $\mathrm{CV}$ at the ITIES. This simple and effective electrochemical approach is based on the variation of the interactions between the protein and the organic electrolyte anion induced by the presence of urea in the aqueous phase. Parameters such as percentage unfolding, free energy of folding and protein compactness can be extracted from these experiments, leading to label-free biophysical studies of non-redox active proteins at the ITIES.

\section{Acknowledgements}

This work was supported by Science Foundation Ireland (07/IN.1/B967) and by the facilities support provided by the PRTLI4 INSPIRE scheme (Higher Education Authority Ireland). 
Table 1: Thermodynamic parameters obtained by absorbance and electrochemical measurements

\begin{tabular}{c|c|c|c|c}
\hline & \multicolumn{2}{|c|}{ This work } & \multicolumn{2}{c}{ Ref. [6] } \\
\hline Method & $\begin{array}{c}\boldsymbol{m} / \mathbf{k J} \\
\mathbf{m o l}^{-2}\end{array}$ & $\Delta G_{W} / \mathbf{k J ~ m o l}^{-1}$ & $\boldsymbol{m} / \mathbf{~ J ~ m o l}^{-2}$ & $\Delta G_{W} / \mathbf{k J ~ m o l}^{-}$ \\
$\mathbf{1}$ & $3.1^{\mathrm{a}}$ & $10.0^{\mathrm{a}}$ & $2.125^{\mathrm{b}}$ & $10.68^{\mathrm{b}}$ \\
\hline Spectroscopy & 2.9 & 11.7 & 1.977 & 8.114 \\
\hline Electrochemistry &
\end{tabular}

${ }^{\mathrm{a}}$ : UV-vis Spectrocopy; ${ }^{\mathrm{b}}$ : Fluorescence spectroscopy 


\section{Figure captions}

Figure 1: $\mathrm{CV}$ of $5 \mu \mathrm{M}$ of $\mathrm{Hb}$ in $10 \mathrm{mM} \mathrm{HCl}(--)$, in $0.15 \mathrm{M} \mathrm{HCl}+0.15 \mathrm{M} \mathrm{KCl}(")$ and in $4 \mathrm{M}$ Urea $+0.15 \mathrm{M}$ $\mathrm{HCl}+0.15 \mathrm{M} \mathrm{KCl}(-)$. The scan rate was $5 \mathrm{mV} \mathrm{s}^{-1}$.

Figure 2: $\mathrm{CV}$ of $5 \mu \mathrm{M}$ of $\mathrm{Hb}$ in $0.15 \mathrm{M} \mathrm{HCl}+0.15 \mathrm{M} \mathrm{KCl}$ in the presence of 2.5 (curve a), 4 (b), 5 (c) 6 (d) and $8 \mathrm{M}$ (e) urea. The scan rate was $5 \mathrm{mV} \mathrm{s}^{-1}$. Inset: Reverse peak current as a function of the urea concentration.

Figure 3: Comparison of the unfolding curves based on UV-vis. absorbance changes at $\lambda=400 \mathrm{~nm}(\boldsymbol{\square})$ and on the peak current changes ( $\square$ ). pH was 0.8 . 
Figure 1

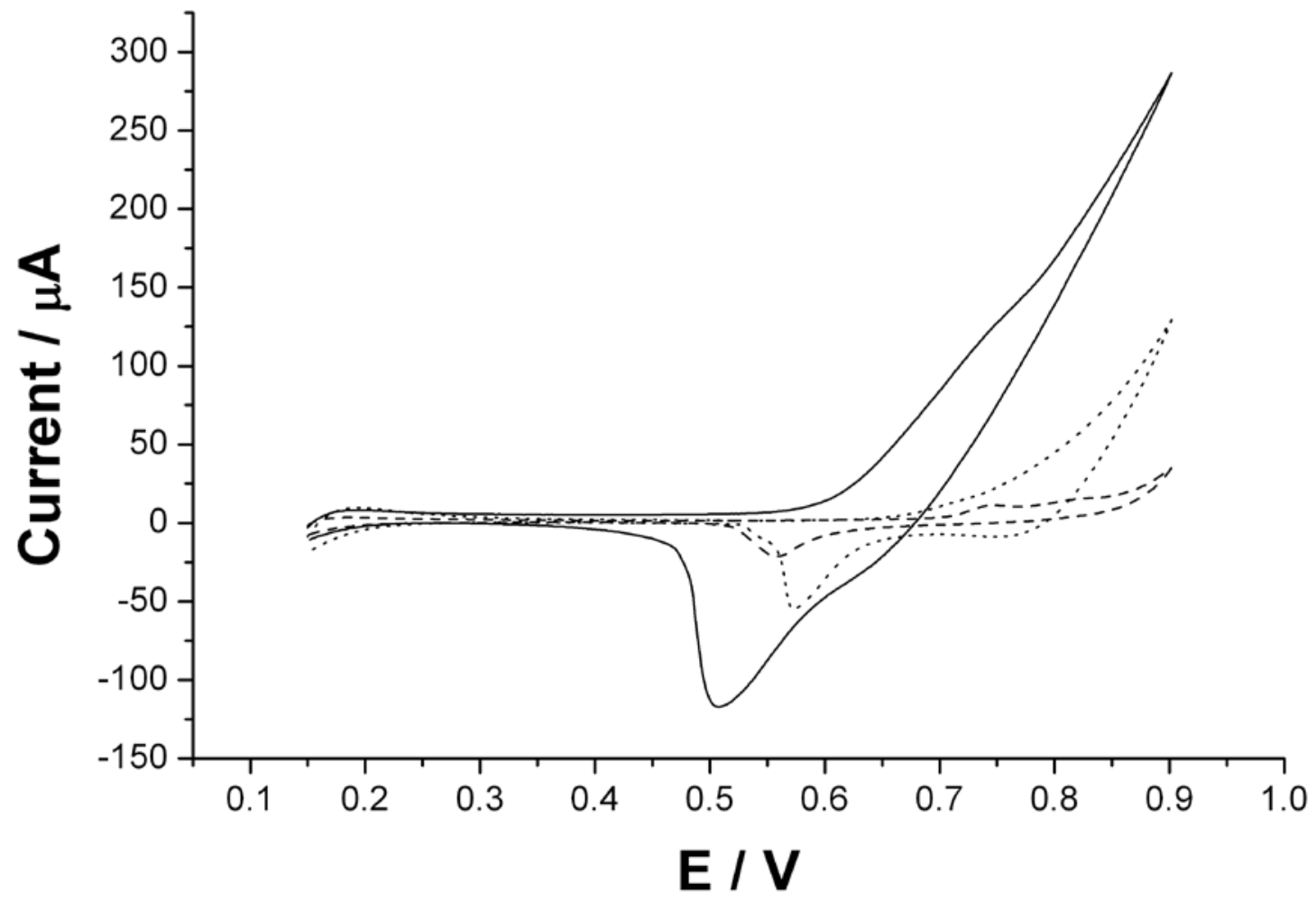


Figure 2

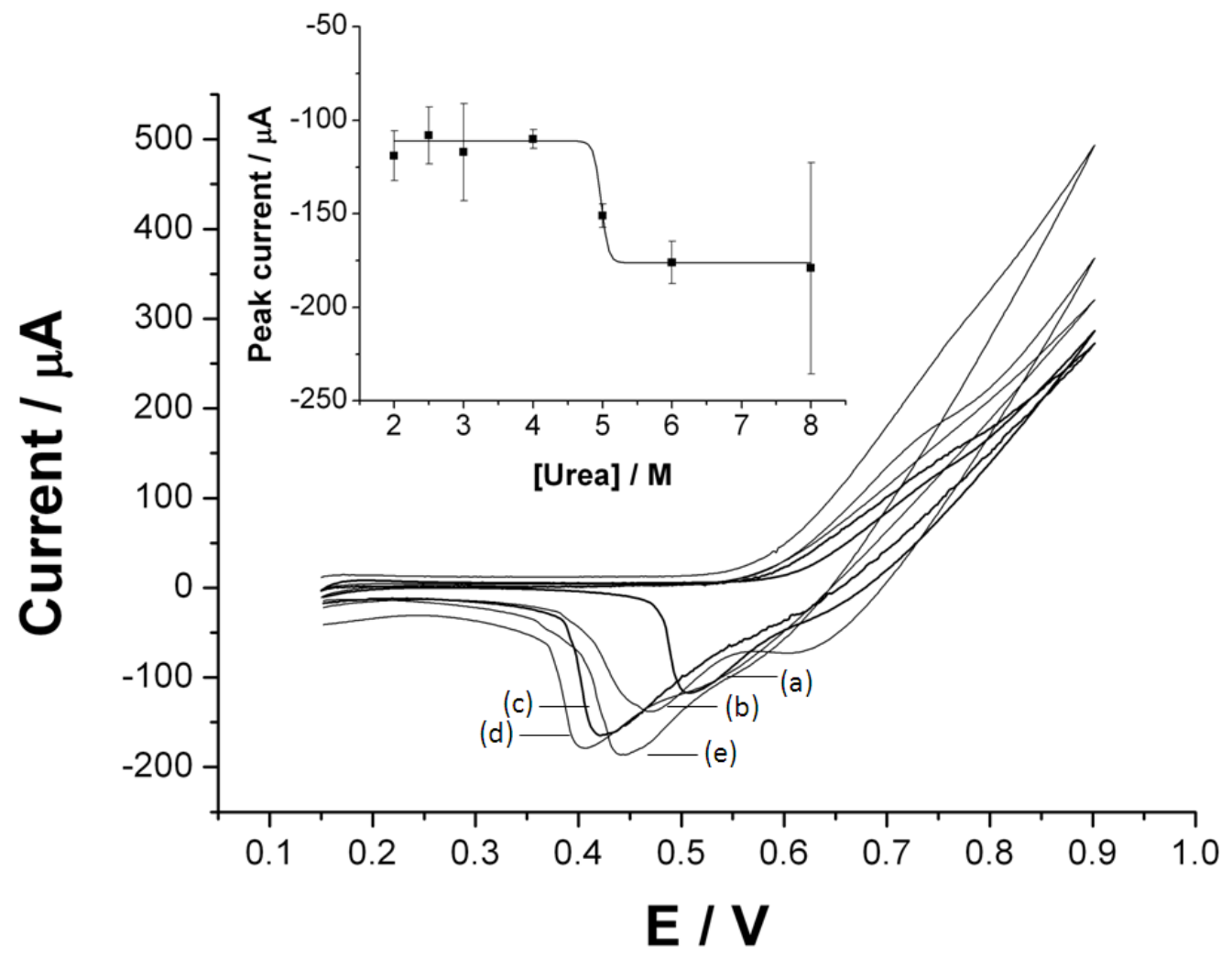


Figure 3

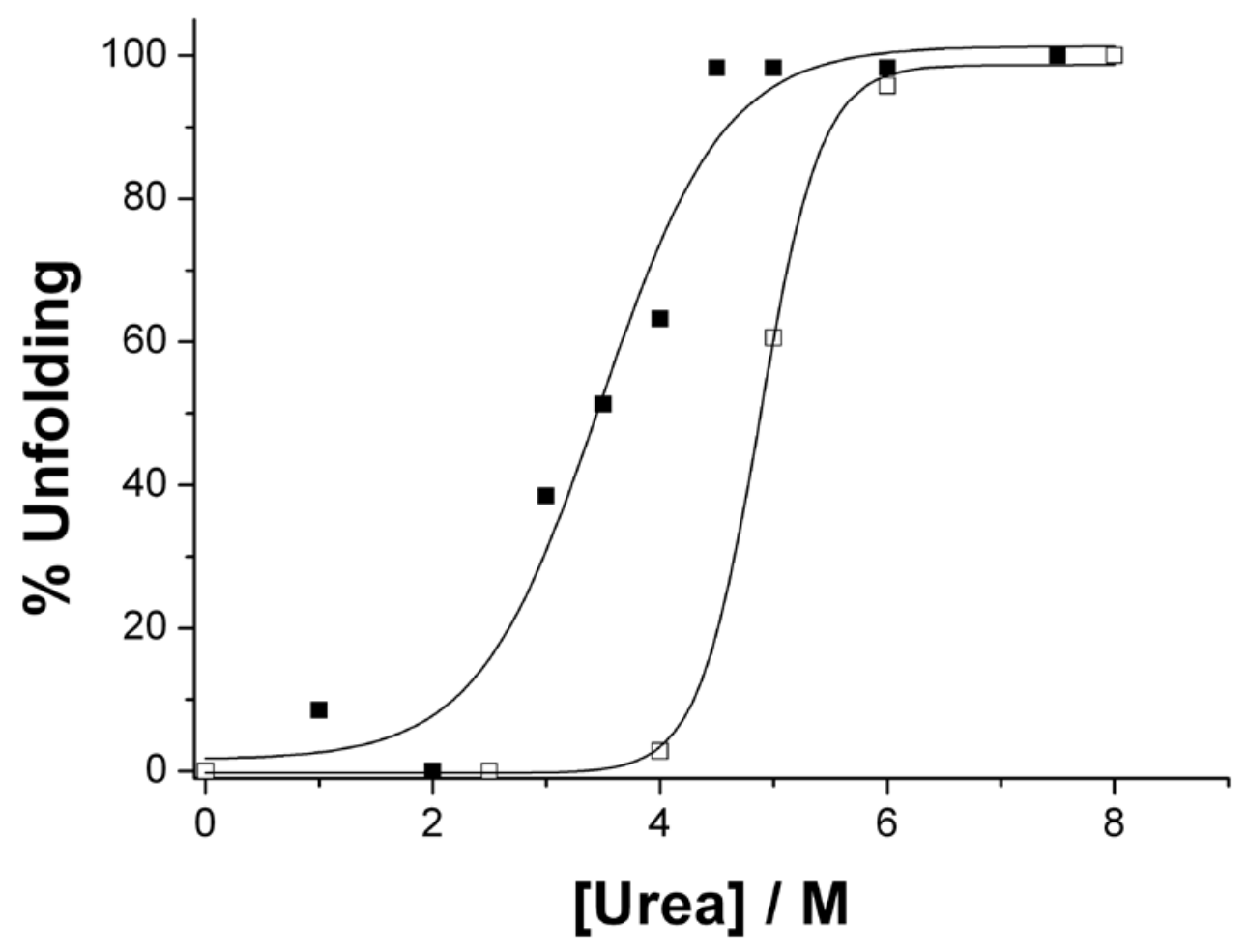




\section{References}

[1] C.N. Pace, M. Scholtz, Measuring the conformational stability of a protein, in: C.E. Creighton (Ed.) Protein structure: A practical approach, Oxford University Press, Oxford, 1997, pp. 299-321.

[2] X. Li, W. Zheng, L. Zhang, P. Yu, Y. Lin, L. Su, L. Mao, Anal. Chem., 81 (2009) 8557-8563.

[3] Z. Mai, X. Zhao, Z. Dai, X. Zou, J. Phys. Chem. B, 114 (2010) 7090-7097.

[4] Q. Wang, W. Xu, P. Wu, H. Zhang, C. Cai, B. Zhao, J. Phys. Chem. B, 114 (2010) 12754-12764.

[5] X. Zhao, Z. Mai, Z. Dai, X. Zou, Electroanalysis, 22 (2010) 2277-2283.

[6] X. Zhao, Z. Mai, Z. Dai, X. Zou, Talanta, 84 (2011) 148-154.

[7] V. Ostatna, H. Cernocka, E. Palecek, J. Am. Chem. Soc., 132 (2010) 9408-9413.

[8] E. Palecek, V. Ostatna, M. Masarik, C.W. Bertoncini, T.M. Jovin, Analyst, 133 (2008) 76-84.

[9] D.G. Georganopoulou, D.E. Williams, C.M. Pereira, F. Silva, T.J. Su, J.R. Lu, Langmuir, 19 (2003) 4977-4984.

[10] G. Herzog, V. Kam, D.W.M. Arrigan, Electrochim. Acta, 53 (2008) 7204-7209.

[11] G. Herzog, W. Moujahid, J. Strutwolf, D.W.M. Arrigan, Analyst, 134 (2009) 1608-1613.

[12] F. Kivlehan, Y.H. Lanyon, D.W.M. Arrigan, Langmuir, 24 (2008) 9876-9882.

[13] M.D. Scanlon, E. Jennings, D.W.M. Arrigan, Phys. Chem. Chem. Phys., 11 (2009) 2272-2280.

[14] M.D. Scanlon, J. Strutwolf, D.W.M. Arrigan, Phys. Chem. Chem. Phys., 12 (2010) 10040-10047.

[15] M. Shinshi, T. Sugihara, T. Osakai, M. Goto, Langmuir, 22 (2006) 5937-5944.

[16] J.S. Ellis, S.Q. Xu, X. Wang, G. Herzog, D.W.M. Arrigan, M. Thompson, Bioelectrochemistry, 79 (2010) 6-10.

[17] R.A. Hartvig, M.A. Mendez, M. van de Weert, L. Jorgensen, J. Ostergaard, H.H. Girault, H. Jensen, Anal. Chem., 82 (2010) 7699-7705.

[18] G. Herzog, P. Eichelmann-Daly, D.W.M. Arrigan, Electrochem. Commun., 12 (2010) 335-337.

[19] G. Herzog, A. Roger, D. Sheehan, D.W.M. Arrigan, Anal. Chem., 82 (2010) 258-264.

[20] D.J. Clarke, D.J. Schiffrin, M.C. Wiles, Electrochim. Acta, 34 (1989) 767-769.

[21] C. Fronticelli, E. Bucci, Biophys. Chem., 23 (1985) 125-128.

[22] N.U. Meldrum, Biochemistry, 25 (1931) 1498-1512.

[23] H.G. Kristinsson, J. Agric. Food Chem., 50 (2002) 7669.

[24] T.T. Herskovits, H. Jaillet, B. Gadegbeku, J. Biol. Chem., 245 (1970) 4544.

[25] B.J. Bennion, V. Daggett, Proc. Natl. Acad. Sci. U. S. A., 100 (2003) 5142-5147.

[26] J.L. England, V.S. Pande, G. Haran, J. Am. Chem. Soc., 130 (2008) 11854-11855.

[27] R.A. Staniforth, M.G. Bigotti, F. Cutruzzolà, C.T. Allocatelli, M. Brunori, J. Mol. Biol., 275 (1998) 133-148. 